\title{
SZEMLE
}

\section{Fuzzy logika az agrár- és környezetkutatásokban}

\author{
${ }^{1}$ TATÁRVÁRI Károly és ${ }^{2}$ PIROS Attila \\ ${ }^{1}$ Széchenyi István Egyetem, MÉK Víz - és Környezettudományi Tanszék, \\ Mosonmagyaróvár és ${ }^{2}$ Budapesti Müszaki és Gazdaságtudományi Egyetem, Gép és \\ Terméktervezés Tanszék, Budapest
}

\section{Bevezetés}

A nyugati tudományos gondolkodás Arisztotelész óta próbálja belekényszeríteni a tudományos értékítéletet az igaz és hamis értékek világába. Azonban rendszeresen felmerül az igény, hogy többértékü logikát alkalmazzunk. Több neves feltaláló (pl.: Kempelen Farkas, Neumann János) járult hozzá valamilyen módon a fuzzy logika kialakulásához. Az úgynevezett „lágy természettudományok" (biológia, orvostudomány, agrártudományok) és a társadalomtudományok területén nehezen meghatározható jelenségeket kell kezelni. SELYE (1967) kifejti, hogy egy biológiai kísérlet eredménye csak akkor tekinthető elfogadhatónak, ha azt sokszor megismételjük, és ezen ismétlések eredményei legalább erősítik egymást. Ebben már látható a többértékủ logika, hiszen nem azt követeli meg, hogy feltétel nélkül minden mérés mutassa ki a hatást (KóCZY és TIKK, 2001).

A fuzzy rendszerek KonCSOS et al., (2011) szerint a halmazelmélet kiterjesztéseként értelmezhetőek. A klasszikus halmazelméletben egy elem vagy eleme a halmaznak, vagy nem, de az adatokról nem mindig állapítható meg egyértelmüen, hogy a vizsgált halmaz elemét képezik-e.

A fuzzy halmazokat egy tagfüggvénnyel kell jellemezni $(\mu)$, ami minél közelebbi értéket vesz fel az egyhez, az elemek annál pontosabban tartoznak az adott halmazhoz (KONCSOS et al., 2011).

A fuzzy rendszerek alapjait HALMOS, (1914) és ZADEH, (1965, 1973) dolgozta ki. A következő években MAMDANI és AssiLILAN (1975) Zadeh módszerét leegyszerüsítve alkotta meg a mai napig is használt úgynevezett Mamdani módszert (KóCZY és TIKK., 2001).

Az 1980-as és 90-es évek elején főleg a különböző tagsági függvények összehasonlító elemzésével foglalkoztak a kutatók, ilyen elemzéseket végeztek például DOMBI (1988), és BLOCH \& MAITRE (1995). Ma már a különböző tudományágaknak, alkalmazási területnek megfelelően több lehetséges módszer áll rendelkezésre a kapcsolatok leírására (KLIR és Bo YUAN, 1995; MCNEILL és THRO,

Postai cím: TATÁRVÁRI KÁROLY, SZE-MÉK, Víz - és Környezettudományi Intézet, 9200 Mosonmagyaróvár, Lucsony u. 15-17.

E-mail: tatarvarik@gmail.com 
1994). Az irányítási rendszerekre KovÁcs (1993), TóTH és JóNÁs (2014) az üzleti folyamatok mérésére és a nyelvi változókra alkalmazható fuzzy halmazokat, függvényeket, módszereket foglalták össze. A talajtani kutatásban való lehetséges fuzzy modellek alkalmazásáról RAJKAI (2001) Modellezés és modellhasználat címü átfogó tanulmányában tesz említést. DELCOURT \& DELCOURT (1988), HoOSBEEK és BRYANT (1992) nyomán a modelleket szerveződési szintjük alapján, hierarchikus rendszerü összefoglalásban mutatja be. A közölt táblázat szerint a fuzzy clustering mérési és becslési eljárás hidrológiai és tömegegyensúly modellek esetében talajrégió léptékben alkalmazható.

CORNELISSEN et al. (2001) a fenntartható mezőgazdaság termelési rendszereinek értékelésében SzABÓ et al. (2005) a talajtérképezési módszereknél, ASTEL (2007), PECHE és RODRIGUEZ (2009, 2012) a környezetvédelmi vizsgálatoknál alkalmazta a fuzzy módszert. PECHE és RODRIGUEZ (2012) szerint ez kifejezetten alkalmas arra, hogy a talajok fizikai - kémiai vizsgálatának adatait a gyakorlatban jól használjuk fel.

MURMU és BISWAS (2015) rámutat arra, hogy a hagyományos képértékelésnél a vegyes pixelek nem a megfelelő kategóriába kerülnek, vagy értékelésük elmarad, mivel ezek nem sorolhatóak egyetlen homogén kategóriába sem. Véleményük szerint e problémára megoldást jelenthetnek a fuzzy rendszerek, amennyiben az egyes pixeleket tagsági függvények segítségével aszerint értékeljük, hogy mekkora mértékben esnek az egyes kategóriákba. Ez különösen akkor elönyös, ha a növényállomány heterogén.

Cikkünkben áttekintjük a fuzzy logika, a lágy számítási módszerek talajtani, agrár- és környezettudományokban való alkalmazását. A szakirodalomban fellelhető tanulmányok többsége a müszaki területen történő használatra koncentrál (pl.: PIROS és VERES, 2013), igaz, esetenként a környezettudományt is érintve, mint például TAMÁS et al. (2012) tanulmánya a biogáz reaktorok fuzzy rendszerekkel történő optimalizálásáról, ENEA és SALEMI (2001) akik az úthálózatok környezeti hatásait mérték fel. A 90-es évektől olyan sok szakcikk jelenik meg mezőgazdasági, természettudományi, meteorológiai (PONGRACZ et al., 2011) területekről is, hogy az áttekintés nem végezhető el a teljesség igényével. Az alkalmazható függvények, a módszerek bemutatása, összehasonlítása egyenként is külön tanulmányt igényelne.

\section{Fuzzy logika a talajtani és környezettudományokban}

A fuzzy logika legnagyobb erössége, hogy közelebb áll az emberi gondolkodáshoz, mint az egyszerü kétértékü fogalmi rendszer (MCBRATNEY és ODEH (1997)).

Az áttekinthetőség javítására a talajtani alkalmazás lehetőségeiről megjelent közleményeket két csoportba rendezve tárgyaljuk:

1. talajok térképezése és osztályozása, földértékelés,

2. talajfizikai folyamatok modellezése és szimulációja, eróziós kutatások. 
(A számos átfedés miatt a két fejezet közel sem homogén. Jobb csoportosítást készíteni tipikus fuzzy feladat, de elvégzése nyilvánvalóan értelmetlen lenne.)

\section{A talajok térképezése és osztályozása, földértékelés}

A talajtani térképezés területén az 1980-as években megjelent közlemények már elöre vetítik, hogy a fuzzy rendszerekkel a Boole logikánál (MONK, 2016) megfelelőbben lehetne ezeket az információkat tárolni, térképszerüen ábrázolni (ROBINSON és STRAHLER, 1984; BURROUGH, 1986;).

BURROUGH (1986) a Boole algebrával, logikával készített GIS térképek lehetséges alternatívájaként említi a fuzzy logika GIS alkalmazását. A 90-es években ezekből a munkákból több mintaprojekt megvalósult, ilyen KolliAS és VOLIOTIS (1991) talaj információs rendszere, amely fuzzy rendszerre épült és fuzzy módszerrel lehet keresni, illetve lekérdezni annak adatbázisában.

BURROUGH (1989) fuzzy logika alkalmazásával a termőréteg vastagságát vizsgálta. A termőréteg vastagsága alapján adta meg a különböző fuzzy részhalmazokat. A módszert a kemény logikai módszereknél alkalmasabbnak ítélte a termőréteg vastagsága alapján történő talajértékelésre.

BURROUGH- hoz (1989) hasonlóan MCBRATNEY (1992) is kidolgozott egy hasonló talajértékelési rendszert fuzzy logikával. Kiindulási gondolatuk szerint, mivel a talajra sok tényező gyakorol hatást, a ma is sokszor használt kategóriák (pl.: erózióra érzékeny, nem erózió érzékeny stb.) a fuzzy logikai módszerrel pontosíthatók. Annak a FAO (1976) által megfogalmazott kívánalomnak próbáltak megfelelni, hogy legyen egyértelmủ a talajtani, földhasználati osztályok kialakítása. Véleményük szerint a Boole algebra szerint készített modellekben sok adat veszik el az egyszerüsítések, általánosítások miatt. A kategóriák kétértelműségének, a bizonytalanság és pontatlanság kezelésének lehetőségét mindketten a fuzzy logika alkalmazásában látták. A fuzzy rendszerek lehetővé teszik számunkra, hogy környezetünket pontosabban tudjuk leírni.

SUI (1992) bemutatott egy GIS fuzzy alkalmazási lehetőséget a városi területek földértékelésének kidolgozására, mellyel a társadalmi-gazdasági viszonyokról jobb képet kapunk, mint a hagyományos GIS rendszereknél.

ZHU et al. (1996) automatizált rendszert épített fel GIS és fuzzy logika segítségével. Írják, hogy a pontos talaj-információk elengedhetetlenek bármilyen ökológiai modellezési- és menedzsment- tevékenység során. Megállapítják, hogy a polygon alapú talajtérképek néhány komoly hibával rendelkeznek, melyeket nagyrészt a kartográfiai módszerek éles határvonalai okoznak. Ezek a hibák a talaj és a táj folytonosságának, kontinuitásának elvesztéséhez vezetnek. Bemutatnak egy lehetséges fuzzy és GIS módszert e hibák kiküszöbölésére. Úgynevezett „talajhasonlóság” (SSV: soil similarity vektor) vektort alkalmaznak, amely segítségével a helyi talajtulajdonságok köztes vagy tipikus értékekböl következtethetőek. Előzetes eredményeket mutatnak be a módszerrel kísérleti vízgyüjtő területen. A talajtani és környezetvédelmi kapcsolatok vizsgálatára strukturált tudásszerzési technikákat, fuzzy logikát, a környezeti változók levezetésére GIS technikákat alkalmaztak. A módszer nagy előnye, hogy nem fedi 
el a részletes talajtani határvonalakat. Megjegyzendő, hogy a határterületeken az eredményeket ellenőrizni szükséges.

Talajfoltossági vizsgálatokat végeztek MCBRATNEY és ODEH (1997), egy ODEH által 1996-ban publikált módszerrel, az úgynevezett többszempontú döntési (MCDM: Multiple-criteria decision analysis) megközelítéssel. A talaj foltossága utalhat például annak vízgazdálkodási tulajdonságaira, humusztartalmára, az eróziós károk mértékére. A foltosságot több egyéb tényező mellett okozhatja a talajt alkotó részecskék mérete, színe, és kontrasztja. A sok tényező miatt nehéz a kategóriákat elkülöníteni, meghatározni, hogy mi a pontos határa a különböző tényezők által okozott foltosságnak. A foltosság mértéke szerint, a fuzzy logikai szabályoknak megfelelően több kategóriát különítettek el. Az MCDM megközelítés jól alkalmazható a talaj redox folyamatainak, valamint morfológiai tulajdonságainak leírására.

TAMÁs et al. (1997) nehézfém tartalmú szennyvíziszapok kihelyezésének kockázati elemzését végezték el hagyományos és fuzzy logikával. A toxikus elemek mozgását a következő főbb talajtani adatok segítségével vizsgálták: agyagtartalom, pH és szerves anyagtartalom. A modelleket hagyományos (Boolean) (MONK, 2016) és fuzzy GIS (az IDRISI Fuzzy sigmoid moduljával) technikával készítették el (EASTMAN et al., 1993.), majd az eredményeket összehasonlították. A hagyományos módon készített elemzések szerint a vizsgált terület 24,9\%-a, míg a fuzzy logikával felépített modell szerint $43 \%$ volt alkalmas szennyvíziszap kihelyezésére. A fuzzy technika pontosabbá tette a környezeti kockázatok becslését.

DOBERMANN és OBERTHÜR (1997) Fülöp - szigeteki öntözött rizsföldek termékenységét 384 termelőnél, összesen 19.000 ha-on vizsgálta. A mintákat a 0-20 cm-es mélységből gyüjtötték. A földterületek besorolásánál Boole és HEUVELINK \& BURROUGH (1993) fuzzy - Monte Carlo szimulációs eljárását alkalmazták. A Boole vagy „éles” logikával készített talaj termékenységi térképek alábecsülték a súlyosan degradálódott területek nagyságát. A legnagyobb termést korlátozó tényező a kálium hiánya, és a kis cink tartalom volt. A fuzzy - Monte Carlo eljárás különösen jó módszer, ha a besorolásnál nagyfokú a bizonytalanság.

METTERNICHT (1998) távérzékelt adatok segítségével talajok sótartalmának mennyiségi és minőségi vizsgálatát végezte el fuzzy besorolás alapú térképezéssel. A sótürő növényzet elterjedését alkalmazta indikátornak. A növényzet müholdas észlelése során olyan spektrális zavarok lépnek fel, amelyek a sótartalomra és a lúgosságra a terület 19\%-án téves besorolást eredményeztek. Munkája során DOMBI (1990) nyomán $S$ - alakú rugalmas tagsági függvényeket alkalmazott.

STEINHARDT (1998) közepes és kis léptékủ tájértékelési rendszert dolgozott ki fuzzy logikával. Használatát ajánlja a tájértékeléseknél, mert a területek heterogenitása jól kezelhető.

METTERNICHT (2001) regionális szintű tájértékelési rendszert dolgozott ki, amelyben a talajok sótartalma alapján vizsgálta a tájképi elemek változását fuzzy logika segítségével. Távérzékelt adatokat, GIS-t és fuzzy logikát alkalmazott. Kiemeli, hogy a GIS és fuzzy rendszerek közös alkalmazásának egyik előnye, hogy a multi-diszciplináris ismeretek könnyen és gyorsan ötvözhetőek. A rendszer eredményeiből megállapítható volt a változások jellege, valószínűsége és nagysága. 
A rendszer megkülönböztette a sós és lúgos területeket. Meghatározta a lehetséges sótartalom változás irányát, melynek során a terület sóssá, lúgossá, vagy sóslúgossá válhat. Ez gyors módszer a talajok sótartalmának regionális szinten való felmérésére, a sótartalom változásának nyomon követésére.

ASSIMAKOPOULOS et al. (2003) fuzzy GIS technikával készítettek modellt a nitrogén mütrágyázás környezeti hatásainak értékeléséhez és térképi ábrázolásához, JÁSZBERÉNYI et al. (1999) hasonló vizsgálatokat végzett a tápelemek heterogenitásának és felvehetőségének vizsgálatára. Egyetértenek KoLLIAS és Voliotis (1991), McBratney és Odeh (1997), Kollias és Kalivas (1998) és KOLLIAS et al. (1999) tanulmányában leírtakkal, hogy a fuzzy rendszerek az egyszerübb lekérdezhetőség, értelmezhetőség és kezelhetőség miatt alkalmasabbak a talajok osztályozására és az integrált földrajzi és információs rendszerek létrehozására, mint a hagyományos matematikai eljárások. Vizsgálták a nitrátkimosódás, a talaj savanyodás veszélyét, az ammóniaként távozó nitrogén mennyiségét, a különböző kijuttatási technológiák hatásait. SILVERT (2000) átfogó tanulmányában a fenéklakók hatását elemzi fuzzy módszerrel egy halgazdaság esetében.

METTERNICHT (2003) szikes talajok Landsat adatainak felhasználásával a hagyományos és a fuzzy osztályozás különbségét vizsgálta modellezett térképeken. PLYUSNIN (1964) osztályozási rendszerét alkalmazta, melyben a szikes talajok a klorid-, szulfát- és karbonát-anion arányok alapján vannak besorolva. Egyszerü háromszög tagsági függvényt alkalmazott a fuzzy besorolás során. A megközelítés alapja, hogy nem minden só egyformán káros, és kezelésük is eltérö módszereket igényel, ezért érdemes meghatározni a különböző sótartalmú talajfoltok térbeli elhelyezkedését. Lehetővé teszi a természetes sótartalom változásának követését. A tapasztalatok alapján a módszer pontosságát javítani kell, de megfelelő szakértelem mellett használható. BRAGATO (2004) talajosztályozást és térképezést végzett fuzzy c - means (FCM) módszerrel (BEZDEK, 1981) és a FuzME szoftver segítségével (MiNASNY és MCBRATNEY, 2002). Leírja, hogy az általánosan használt regionális földhasználati térképek osztályozási skálája nem elég részletes, nem praktikus. A geostatisztikai módszerek és az FCM együttes használata jelentősen javít ezen, ha a talajok változása egyik típusról a másikra fokozatos és nem könnyen figyelhető meg a felszínen.

AMINI et al. (2005) talajszennyezés térképezést folytatott fuzzy logika és térbeli interpoláció segítségével Isfahanban, Irán központi államában. 255 minta kadmium, ólom, cink, réz és kobalt koncentrációját vizsgálták a termőtalaj 0-20 cmes rétegéből. A fuzzy osztályozást FCM algoritmussal (fuzzy c-means; BEZDEK et al. (1984); ODEH et al. (1992)) végezték, amely a talajtani kutatásokban az egyik leggyakrabban alkalmazott módszer. Nehézfémtartalmuk szerint a talajokat négy osztályba sorolták. ILLÉS et al. (2006) GIS alapú digitális talajtérképezést végeztek fuzzy logika szerint magyarországi erdőgazdálkodási területeken (Hanság, Széki erdő és Várhegy). A modellezés során a talajadottságok és a környezeti tényezők kapcsolatának feltárására törekedtek.

SÁRBU et al. (2007) talajminták hierarchikus klaszterezését végezték el fuzzy FCM módszerrel (BEZDEK, 1981; BEZDEK et al., 1999) és Gustafson - Kessel 
algoritmus (GUSTAFSON \& KeSSEL, 1979) segítségével. 304 talajminta Cd, Co, Cr, $\mathrm{Cu}, \mathrm{Eu}, \mathrm{Fe}, \mathrm{Mn}, \mathrm{Ni}, \mathrm{Pb}, \mathrm{Sb}, \mathrm{Se}, \mathrm{Y}$ és Zn-koncentrációját határozták meg négy lépésből álló szekvenciális eljárással, URE et al. (1993 a, b) szerint: ecetsav (1), hidroxiammónium- klorid(2), a hidrogén-peroxid / ammónium-acetát (3) és desztillált víz (4). Céljuk az elemek toxicitása és talajban, üledékekben való mobilitása közti összefüggés vizsgálata volt. Hierarchikus és horizontális fuzzy csoportosítást végeztek. A Gustafson - Kessel algoritmus érzékeli az egyes klaszterek eltérő alakját. Az alakfelismeréssel dolgozó rendszerek tényleges előnyökkel rendelkeznek a környezeti mutatók elemzésénél.

LÓPEZ et al. (2008) talajok szennyeződési kockázataival foglalkoztak, különböző szennyezők esetén. Az általuk felépített modellt (Soil Risk Characterization Decision Support System (SRC-DSS)), melyet cikkükben részletesen leírnak, az azt megelöző döntéstámogatási modellel (Decision Support System (DSSs) (Hu et al., 2003)) vetették össze. Az SRC-DSS modell kevesebb paraméterrel dolgozik anélkül, hogy fontos részletek vesznének el. Kiváló segítség a környezetvédelmi döntések meghozatalához, a kármentesítési technológia kiválasztásához.

FERRARO (2009) tudásalapú modellt (KBS = knowledge based system) épített Argentin növénytermesztési rendszerekhez IF - THAN kapcsolatokkal. A KBS célja a talajállapot értékelése szakértői vélemények és tudományos adatok alapján. Három bemenettel: talajvizsgálati adatok, környezeti és termesztéstechnológiai feltételek, valamint szakértői értékelés. A modellt kukorica, búza és szója növényekre alkalmazva azt találták, hogy a vizsgált talajaik humusztartalma, fizikai, fizikai-kémiai tulajdonságai jók, de nitrogénszolgáltatása csak a várható termés felét fedezi. A modell jól alkalmazható akkor is, ha nem áll rendelkezésre megfelelő mennyiségü és pontosságú adat az agroökológiai állapot megítéléséhez.

HODZA (2010) fuzzy logikával vizsgálta a tradicionális és a virtuális térképezési technikával készített térképek eltéréseit. Tanulmányában megállapítja, hogy a leíró, magyarázó jellegü térképek és a pontos talajtérképek között jelentős (43\% - os) eltérés is lehet. A különbségek oka az alkalmazott technikában, és a térképet készítők személyében keresendő, de szaktudás nélkül a fuzzy módszerrel készített térképek sem lesznek pontosabbak. Javasolja, hogy a talajtérképezés során ne egyéni adatbázisokat és térképeket hozzanak létre, hanem egy egységes adatbázisból dolgozzanak.

PARCHAMI et al. (2010) $\mathrm{CdNO}_{3}$-al szennyezett talajon tesztelték a fuzzy módszer alkalmazhatóságát. A Cd akkumulálódását retek és zsázsa tesztnövényeken vizsgálták, hagyományos és fuzzy p - érték módszerrel (FILZMOSER \& VIERTL, 2004; PARCHAMI et al. 2010). Bemutatták, hogy fuzzy módszerrel jobban kezelhetők a talaj-növény rendszerek, míg a fuzzy alkalmazása nélkül az eredmények félrevezetők lehetnek.

ZHU et al. (2010) a talaj és környezet kapcsolatainak feltárására vállalkoztak egy $60 \mathrm{~km}^{2}$ nagyságú vízgyüjtő területen. Áttekintést adnak a fuzzy halmazelméletet széleskörủ alkalmazásáról a talajosztályozás és térképezés, ill. a földértékelés területén. Eljárásuk és a hozzá kidolgozott mintavételi technika kimondottan alkalmas olyan területek térképezésére, melyekről kevés információ áll 
rendelkezésre. Az A - szint humusztartalmának feltérképezése során 76\%-os pontosságot értek el.

CANIANI et al. (2011) 118 ellenőrizetlen hulladéklerakó területén osztályozta a talajszennyeződés veszélyét fuzzy logika segítségével. Veszélyességi skálát állítottak fel. Az input adatok a következők voltak: a talajvízszint mélysége, a terület lejtése, a csurgalékvíz és a hulladék mennyisége, a lerakott hulladék milyensége és a folyóvíz közelsége. 55 különböző modellfuttatást végeztek és megállapították, hogy a tagsági függvényeket körültekintően kell megválasztani, ellenkező esetben teljesen eltérő eredményeket kapunk. Egy olyan módszert kívánnak kifejleszteni, amely képes a különböző paraméterek közötti kapcsolatok tanulására (,neuro-fuzzy módszer”).

GRUIJTER et al. (2011) digitális talajértékelést végeztek fuzzy logika és hagyományos módszer segítségével, céljuk a mintaterületen a vetőburgonya termesztésre alkalmas területek felmérése volt. Tapasztalatuk szerint a hagyományos és fuzzy módszerrel készített térképek jelentős mértékben nem tértek el. Azonban, a fuzzy logikával készített térképeknél értékelhetőek az elmosódó határvonalak is. A fuzzy módszer alkalmazhatóbb akkor, amikor egy tulajdonság mellé nem lehet egyértelmüen meghatározott értékeket rendelni. Nem ritka, hogy a talajt egy adott osztályhoz rendelik, míg a gyakorlati tapasztalatok szerint nem abba az osztályba kellene tartoznia. A fuzzy modellel ezek, az általában határterületekre eső talajok is osztályozhatóak, így a fuzzy logikával készített térképek több információt hordoznak. Bár a fenti kutatásokban egybehangzóan kijelentik, hogy a térbeli elemzésben ezek a sikerek kezdetinek tekinthetők, mindenképpen javasolják a további kutatásokat, különös tekintettel azok alkalmazhatóságára a földértékelésben.

DAVATGAR et al. (2012) helyspecifikus gazdálkodási rendszert hoztak létre geostatisztikai technikával, főkomponens analízissel és fuzzy klaszter algoritmus segítségével. 24000 ha rizsföldet vontak be a vizsgálatba, amelyről mindössze 303 talajmintát gyüjtöttek be. Mérték az agyagtartalmat, a pH-t, a kation-cserélő kapacitást, a szerves szén, az összes nitrogén, a „felvehető foszfor” és -kálium mennyiségét. Ezek térbeli változékonysága alapján 4 menedzsment zónát különítettek el és megállapították, hogy az eredményes rizstermesztés legfőbb akadálya a „felvehető kálium” nagyon heterogén területi eloszlása. Ez lehetőséget adott a helyspecifikus mütrágyázási technológiára való áttérésre.

KWEON (2012) szintén helyspecifikus termékenységi zóna lehatárolást végzett talajtulajdonságok és topográfiai adatok segítségével, Kansas hegyvidéki területén. A korábban kijelölt zónák nem voltak elég pontosak helyspecifikus technológiák alkalmazásához. FCM (fuzzy c-means; BEZDEK et al. (1984); ODEH et al. (1992)) algoritmust alkalmazva, a négy számszerüsíthető bemenet mellett (a talaj vezetőképessége, szervesanyag tartalma, a lejtők hossza és a lejtésszög), a területen dolgozók véleményét is figyelembe tudta venni, és az elkészített térképek kielégítő pontosságúak voltak. A módszer különösen elönyös olyankor, ha kevés konkrét adat mellett nem kalibrált, de hasznosnak ítélhető szubjektív megfigyeléseket is fel kívánunk használni. 
GIORDANO és LIERSCH (2012) lokális környezeti monitoring és döntéstámogató rendszert épített fuzzy logika és GIS segítségével a talajok sótartalmának monitoringozására. Céljuk az volt, hogy a helyi szintủ információkat technológiai információkkal ötvözve a fuzzy rendszerek gyorsaságát és adatbeviteli egyszerüségét egy programban ötvözzék a GIS rendszerek elemzési és adatábrázolási tulajdonságaival. Munkájuk során egyszerủ IF - AND - THAN fuzzy kapcsolatokat alkalmaztak, és szabad hozzáférésü GIS-SAGA szoftvert. A lokális és a nagyobb léptékü adatokat, a gazdák tapasztalatait, gazdálkodási információit egy rendszerbe integrálták.

SATTLER et al. (2012) különbözö gazdálkodási gyakorlatok (szerves és integrált gazdálkodás, ásványi és szerves trágyázás, csökkentett vagy hagyományos talajmüvelés) összehasonlítására alkalmas modellt készítettek IF, AND, THAN függvények növényfajonként való alkalmazásával. Az általuk bevezetett IS „Fenntarthatósági Index” (Index of sustainability) mutatja, hogy az egyes termelési technikák milyennek ítélhetők a biológiai sokféleség megőrzésének szempontjából. A módszer alkalmas a nem numerikus, szubjektív információk beépítésére. A fuzzy technikát gyakran alkalmazzák döntéstámogató rendszerek készítéséhez. SAMI et al. (2014) környezet-értékelő modellt hozott létre mezőgazdasági vállalkozások részére, míg WANG et al. (2014) hasonló tanulmányukban nehézfémmel szennyezett talajok kármentesítési technológiájának kiválasztásához adnak segítséget.

MURMU és BISWAS (2015) növényállományok öntözési igényének megállapítása céljából távérzékelt képek értékelését szolgáló „lágy” és „kemény” matematikai eljárásokat hasonlítottak össze. A hagyományos képértékelésnél, különösen, ha a növényállomány heterogén, nagy probléma, hogy a vegyes pixelek nem a megfelelö kategóriába kerülnek, esetleg értékelésük el is marad, mivel nem sorolhatóak egyetlen homogén kategóriába sem. A lágy számítási technikákkal (fuzzy rendszerek, neurális hálózatok, evolúciós algoritmusok) azt határozzuk meg, hogy az egyes pixelek mekkora mértékben esnek az egyes kategóriákba. Ezek segítségével az öntözéssel kijuttatandó víz mennyiségére pontosabb és megbízhatóbb értékeket kaptak.

2. A talajfizikai folyamatok modellezése és szimulációja, eróziós kutatások

BÁRDOSSY et al. (1990, a. b.) szerint a talajtani folyamatok sokrétüsége, a definíciók (pl.: talajmorfológiai meghatározások) és analitikai modellek bonyolultsága és bizonytalansága miatt megfelelő lehet a „puha logika”, fuzzy logika alkalmazása ezeken a területeken. BÁRDOSSY és DUCKSTEIN (1995) leírja, hogy a környezeti modellezést az alkalmazott nagy mennyiségü paraméter nehézzé teszi, illetve, mivel a különböző paraméterek általában nem lineáris módon változnak, az eredmények, azok kismértékü változására is érzékenyen reagálnak. Ennek ellenére a matematikai egyenletek, modellek alkalmazása elkerülhetetlen a különböző folyamatok becslésére, még, ha azok alkalmazhatósága sok esetben megkérdőjelezhető is. 
WATERSTONE (1994) szerint az úgynevezett kemény matematikával, készült modellek nehezen értelmezhetök, nem képesek tükrözni a talajban valóban lejátszódó komplex folyamatokat.

BÁRDOSSY és DUCKSTEIN (1995) az általuk készített földtani közeg (talajszelvény) nedvességtartalom modellt összevetették az általánosságban használt hasonló modellekkel. A fuzzy modell tanulmányuk szerintük egyértelműen jobban teljesít, mint az általános. Egyelöre csak felülről történő beszivárgással számoltak. $\mathrm{Az}$ általuk használt fuzzy Richards modellel történő számolás kevésbé volt időigényes és jobb eredményeket szolgáltatott, mint más, a talajnedvesség alakulásának leírására alkalmazott modellek.

MCBRATNEY és ODEH (1997) szerint a fuzzy logika egyik legfontosabb alkalmazási területe lehet a termőréteg vízgazdálkodásának modellezése, mivel összetettsége miatt azt nagyon nehéz becsülni. Pórusszerkezet modellezéséhez MCBRATNEY és MORAN $(1994 ; 1997)$ gyantával impregnált mintákról készített két és háromdimenziós digitális felvételeket. A felvételeken a homályos határok miatt a szemcsék és pórusterek megkülönböztetése nagy nehézséget jelentett. Olyan fuzzy modellt dolgoztak ki, amely bináris eljárásoknál alkalmasabb volt a szürke árnyalatos képek elemzésére. Véleményük szerint az eljárás alkalmassá tehető a levegö- és folyadék-fázis megkülönböztetésére, illetve a talajok zsugorodásának és tömörödésének modellezésére.

FREISSNET et al. (1998) talajvíz és az abban oldott anyag mozgását modellezték. Példaképpen bemutatják az atrazin szennyezés terjedését egy meszes talajon. Tanulmányukban mintegy összefoglalását adják a fuzzy módszer modellezésben való alkalmazásának előnyeit: a környezetünkben lejátszódó folyamatok leírására szolgáló matematikai modellek mindig közelítőek, de a bizonytalanság megsokszorozódik az elmosódott határok nem megfelelő kezelése miatt. A fuzzy módszer figyelembe veszi a minőségi és mennyiségi pontatlanságokat, rugalmasan kezeli az egyszerüsítésekből és hiányos adatsorokból származó hibákat.

Az esőzések által okozott talajveszteség, az erózióérzékenység becslésére gyakran használt univerzális egyenlet (USLE) helyett, az eróziós folyamat leírására egyre többször olyan modelleket, szoftvereket (RAINES et al., 2010) alkalmaznak, melyekbe már be van építve a fuzzy logika.

ZADEH már 1965-ben úgy fogalmazott, hogy a különböző földrajzi adatok, paraméterek feldolgozásához, a kontinuitásból adódó bizonytalanság, és a nagy környezeti változékonyság miatt ajánlott fuzzy logikát alkalmazni (ZADEH, 1965).

MAYS et al. (1997) földhasználati kockázatértékelő rendszert készítettek. A kockázatot egy „integrált veszélyességi index” jellemezte, melynek lényege a földcsuszamlások kockázatának becslése volt a mintaterületen, a tagsági függvényeket a talajok mechanikai összetétele szerint határozták meg. MITRA et al. (1998) az USLE (Universal Soil Loss Equation) alkalmazhatóságát vizsgálta fuzzy logikával kombinálva nagy vízgyüjtő területen. Kutatásukat a következő hipotézisek köré építették fel: 1. korlátozott számú bemeneti változóval talajeróziós becsléseket végezni fuzzy logika segítségével; 2. meghatározni, hogy az input adatok mennyiben határozzák meg a felépített modell hatékonyságát; 3 . 
összehasonlítani a hagyományos USLE egyenlet és a fuzzy modell hatékonyságát. Két fuzzy logikával működő modellt építettek, az első két bemeneti változót (a terület meredekséget és a földhasználat aránya), a második három paramétert alkalmazott (talajerodálhatóság, növény borítottság, lejtő hossza). $30 \mathrm{~m}$ felbontású GIS adathalmazokat, trapéz alakú tagsági függvényekkel alkalmaztak. Kimutatták, hogy a fuzzy logika egy viszonylag egyszerü módja a talajeróziós potenciál meghatározásának. Leírják, hogy az eltérő raszter nagyságra (1:24000 ill. 1:25000) a modellek érzékenyen reagáltak, kis erózió érzékenységü területeket a modell nagyobb erózióérzékenységünek tüntetett fel. Véleményük szerint regionális szinten alkalmazhatók a bemutatott modellek, különösen arra tekintettel, hogy a regionális becslés alapján kijelölhetőek azok a területek, amelyeken érdemes részletesebb adathalmazokat alkalmazni. A fuzzy logika alkalmazása költséghatékony módszere lehet a talajerózió bármilyen léptékủ modellezésének. Véleményük szerint, mivel a kétváltozós modell erős korrelációt mutatott az USLE egyenlettel, ezért alkalmazása ajánlott különösen azokban az esetekben, amikor nem áll rendelkezésre megfelelő mennyiségü adat.

FEOLI et al. (2002) az antropogén eredetủ talajpusztulás felmérését végezték el GIS és fuzzy logika segítségével, etiópiai mintaterületen. Céljuk a környezet antropogén eredetű pusztulása és a mezőgazdaság kapcsolatrendszerének feltárása volt. GIS alkalmazásban integrálták a környezeti adatokat, digitális terepmodelleket, növényzetet, eróziós térképeket és társadalmi-gazdasági változókat. A kapcsolatok kiértékelése során úgynevezett „fuzzy hasonlóság mátrix" eljárást alkalmaztak (ZHAO, 1986). Megállapították, hogy az emberi hatások növekedésével csökken a biomassza mennyisége. A népesség növekedésével nem arányos a termelt élelmiszer mennyiségének növekedése. TRAN et al. (2002) a RUSLE (Revised Universal Loss Equation) modellt alkalmazták fuzzy logikával kombinálva. Alkalmasabb volt az erózió becslésére, mint a statisztikai megközelítésen alapuló modell, valós eredményeket adott, a paraméterek közötti kapcsolatokat jobban leírta, kezelte a bizonytalanságokat.

TAYFUR et al. (2003) fuzzy algoritmussal becsülték a csupasz talajfelszín lefolyás általi erózióját. Lejtő dőlésszög és csapadék adatokat használtak bemeneti adatként IF, AND és THAN kapcsolatokkal. Megállapították, hogy a fuzzy modell jobban teljesített erősen változó csapadékintenzitás, és nagyon meredek lejtők esetén. Ennek oka a választott fuzzy tagsági függvények alakja. A fuzzy és ANN (neurális hálózat alapú öntanuló módszerek) (TAYFUR, 2002) módszereket a fizikai alapú modellnél mindenképpen alkalmasabbnak tekintik, mivel ezek alkalmazása nem igényel sok bemenő paramétert, bonyolult numerikus számítási módszereket. METTERNICHT és GONZALEZ (2005) által felépített FUERO (a FUzzy exploratory modell for soil EROsion hazard prediction) modell ok - okozati összefüggéseiben vizsgálja a talajerózió indikátorait (pl.: növényborítottság, kőzettörmelék aránya, termőréteg színe, lejtő gradiens), és a közöttuik lévő kapcsolatokat. A módszerrel tájszinten becsülhető az eróziós hajlam, és alkalmas a szakértői információk adaptálására. GIS rendszerben IF, THAN, OR, AND kapcsolatokat alkalmaztak. A modell a táj erózió érzékenységét alacsony, közepes vagy magas kategóriába sorolja. A modell alternatívája lehet a jól ismert USLE (Universal Soil Loss 
Equation) egyenletnek, vagy RUSLE modellnek, hátránya, hogy nagyobb szakértői tudást igényel.

SABOYA et al. (2006) földcsuszamlás érzékenység vizsgálatokat MAMDANI MAX-MIN (MAMDANI és AsSiLILAN, 1975) stratégiával végeztek Rio de Janeiro területén. Gyors döntéstámogató rendszert hoztak létre az építési célra alkalmatlan területek kijelölésére, 13 paramétert vettek figyelembe, a nyelvi nehézségek ellenére megoldották a korábbi tapasztalatok és a mérnöki megítélés számszerüsítését. A módszer rugalmas és kicsi a költségigénye. AKYUREK és OKALP (2006) az általános talajveszteségi egyenletet (USLE), integrálták a GIS képességeivel és a fuzzy logikával. A modellt a kis helyi vízgyűjtőn tesztelték (Izmir, Kocadere Creek). Az 1987. és 2000. évre elvégzett számítások alapján a talajveszteségi egyenlet kimenő adatait térinformatikai szoftver felhasználásával alacsony, közepes és nagy eróziós kockázati csoportba sorolták és térképi formában ábrázolták. Kísérletképpen megvizsgálták, mi történik, ha csak az USLE modell LS (lejtőhossz és lejtő gradiens) tényezőjét, illetve az LS tényezöt valamint a C (növényzet és növénytermelés) tényezőt veszik figyelembe. Az erős eróziós érintettség kategóriába az LS-C modell szerint 10-20\%-al kisebb terület került. Végeredményben az LS-C modellt sem találták elég pontosnak a teljes USLE egyenlethez képest, ezért kiegészítették a $\mathrm{P}$ faktorral (konzervációs védelmi faktor).

MALCZEWSKI (2006) a földhasználati alkalmasságot elemezte mexikói mintaterületen. GIS alapú területhasználati térképek adatbázisait fuzzy logikával kombinálta, súlyozott átlagolási rendezést (OWA, Ordered Weighted Averaging) alkalmazott (MAKROPOULOS és BUTLER, 2005). Bemutatták, hogy módszerük az emberi gondolkodáshoz közelebb hozza a GIS típusú rendszereket, és lehetővé teszi, hogy a földhasználatot több szempontú értékelés alapján válasszuk ki. COHEN et al. (2008) kidolgoztak egy vízgyüjtő léptékű dinamikus talajerózió modellt (FuDSEM: fuzzy-based dynamic soil erosion model), és ennek időben statikus változatát (FUSEM). A modell térben és időben dinamikus fuzzy alapú egyenleteket alkalmaz. Egyszerủ bemenő adatokat használ, könnyen értelmezhető outputokat képez, melyek nem az erózió mértékét, hanem a potenciálisan veszélyeztetett területeket határozzák meg. A modellt kis és közepes méretü heterogén vízgyüjtőkben tesztelték Izraelben. Csak kvalitatív értékelésre alkalmas. Előnye, hogy laikusok számára is egyértelmüen mutatja a különösen veszélyeztetett területeket, de mérnöki célokra a hagyományos mennyiségi eróziós modelleket kell használni.

MÁrquez és PÉreZ-Guevara (2010) Venezuelában, a Chirgua vízgyüjtő területen összehasonlító elemzéseket végzett a WEPP (Water Erosion Prediction Projekt) (FlanAGEN és NEARING, 1995; KLIK et al., 1995), EUROSEM (European Soil Erosion Model) (MORGAN et al., 1998), és a CIHAM-UC (Centro de Investigaciones Hidrológicas y Ambientales de la Universidad de Carabobo) (SIMONS et al., 1981) modellekkel. A modell futtatások során determinisztikus és empirikus módszereket alkalmaztak, úgymint lineáris és nemlineáris többszörös regressziós, mesterséges neurális hálózatok (ANN) és fuzzy módszerek (FIS). Érdekes, hogy a lineáris regresszióval kapott adatok jobban fedték a valóságot, mint a nem lineáris módszereké. A mesterséges intelligencia-módszerekkel számított 
eredmények és a megfigyelt értékek kielégítően közelítették egymást. A különbözö technikák között a következő volt a rangsor: mesterséges intelligencia technikák (ANN, FIS), fizikai folyamatmodellek, lineáris regresszió és végül a nem lineáris regresszióval végzett vizsgálatok.

HUADING és munkatársai (2010) a szélerózió veszélyeztetettséget értékelték FCM (Fuzzy C-means Clustering) (BEZDEK et al. 1984; ODEH et al. 1992) és GIS (LI et al. 2005) technikával a Mongol fennsíkon. A Mongol fennsíkon a szélerózió a legnagyobb környezeti probléma. A vizsgálatok során négy fő paramétert alkalmaztak: a növényborítottságot, a terület relief energiájának (domborzati viszonyainak) mértékét (CALLOTT et al. 2000), a talaj nedvességviszonyait és a szélsebesség intenzitását, az erózió veszélyeztetettséget hat kategóriába sorolták. A GIS rendszerekben történő adatfeldolgozás során a talaj nedvességtartalmával és a normalizált vegetációs index (NDVI, CARLSON és RIPLEY, 1997) értékekkel kapott mintázat hasonlóságából arra a következtetésre jutottak, hogy a széleróziónál ezek a paraméterek meghatározó szerepet játszanak. A széleróziós veszélyeztetettség a Mongol fennsíkon is szorosan kapcsolódik a táj domináns növényzettípusihoz.

NANDA és munkatársai (2011) tengerparti erózió becslésére valós körülmények között kívánták alkalmazni a fuzzy logikát. Ennek érdekében Indiában, a Puri Sea Beach területén valós idejü monitoring rendszereket építettek ki Genetikai Fuzzy (GFS) módszerrel (NANDA et al., 2010). A tengerparti erózió valós idejü nyomon követése ma a geofizikai kutatások fontos területe. A lágy modellezési módszerek (Soft Computing: SC; KAMPHUIS, 1986), a fuzzy logika (Fuzzy Logic: FL; KARABOGA et al., 2004) és a mesterséges neurális hálózatok (Artifical Neural Networks: ANN; DANIELL, 1991) alkalmasabbak voltak a hordalékszállítás becslésére és előrejelzésére, mint a hagyományos módszerek. Az FL és ANN módszereken belül a legpontosabb eredményeket a gradiens (vagy „hegymászó”; LuH és LiN, 2009) algoritmussal érték el, de ez nagyon időigényes eljárás.

DEMIREL és TÜZÜN (2011) Törökország területének erózió érzékenységét vizsgálták egy általuk kialakított fuzzy modell (ANP - Analitical Network Process, PROMENTILLA et al., 2008) segítségével amely a halmazok bizonytalanságát is tükrözi. Hierarchikus felépítésben a következö változókat használták: időjárás, domborzat, terület, talajjellemzők, földhasználat és talajfedés, antropogén hatások. Outputként az újraerdősítésre, teraszos müvelésre, szélfogók építésére, valamint a helyes gazdálkodási gyakorlat alkalmazására adtak ajánlásokat. Törökországban egyes művelési technológiák a legfőbb okai a talajeróziónak.

Tanulmányukban kifejtik ÖZDEMIR (2002) korábbi tanulmányához hasonlóan, hogy a matematikai modellek egyre inkább megközelítik a valóságot, de nincs olyan modell, amit fenntartások nélkül el lehetne fogadni. A modellek elfogadásához, az eredmények validálására, ehhez pedig interdiszciplináris kutatócsoportra van szükség.

CAMARINHA et al. (2011) vízerózió modellezést végeztek brazíliai mintaterületen, hogy földhasználati ajánlásokat tehessenek. A területet a talaj mechanikai összetételével, mindössze 41 minta alapján jellemezték, 
erózióérzékenységük szerint fuzzy tagsági függvénnyel kategorizálták. Legfőbb céljuk, hogy az esős évszakban csökkentsék az erózió mértékét.

MEZÖSI és munkatársai (2013) szélerózió-érzékenység becslést végeztek Magyarország területén. A következő adatokat használták fel: talaj textúra, szemcseméret, $\mathrm{CaCO}_{3}$ tartalom (AGROTOPO, (1991) adatbázisból), meteorológiai adatok 52 állomás méréseiből (NOAA Nemzeti Éghajlati Adatközpont (2012)), valamint növényborítottság (MODIS NDVI (USGS, 2012)). Nem vizsgálták azon területeket, amelyeken a CORINE LAND COVER (EUROPEAN ENVIRONMENTAL AGENCY, 2006) osztályozása alapján szélerózió nem lehetséges (pl.: erdőterületek, vízterületek). Az egyes paramétereket elöször érzékenységi térképek alapján vizsgálták, majd fuzzy logika alkalmazásával regionális szintủ szélerózió érzékenységi térképet hoztak létre. Az eredményeket helyszíni vizsgálatokkal ellenőrizték, és regionális szintủ becslésre alkalmasnak bizonyultak. Kisebb léptéknél szükséges a felület érdességének, a szelet akadályozó, és irányát, erősségét módosító tényezőknek valamint a parcellák hosszának és irányultságának figyelembevétele is. A készített térkép megmutatja, hogy a magas homokfrakció miatt a Duna-Tisza köze valamint a Nyírség, a nagy lösz- és vályogtartalom, illetve az intenzívebb és gyakoribb szélesemények okán pedig Nyugat-Magyarország talajai a legveszélyeztetettebbek.

ZHU et al. (2014) szakértői tudásalapú modellt készítettek a földcsuszamlásérzékenység feltérképezéséhez. A földcsuszamlásról és a hajlamot meghatározó tényezőkről gyüjtött szakértöi ismereteket dolgozták fel. Bell- Z- és Sfüggvényeket használtak (BURROUGH, 1989), öt lejtőosztályt alakítottak ki. A módszert két mintaterületen tesztelték és megállapíthatták, hogy a számított földcsuszamlás- hajlam értékek jó indikátorai a valódi eseményeknek.

BORELLI et al. (2014) a Pán-Európai régió talajainak szélerózió veszélyeztetettségét vizsgálták. Véleményük szerint a szélerózió kutatása a régióban nem kielégítő, emiatt hatékony talajvédelmi stratégiák kidolgozása nem lehetséges. A régió szélerózióra érzékeny tájegységeinek meghatározásához a széleróziós információkat és a környezeti tényezőket integrálták. Az éghajlat, a talaj, a növénytakaró és a felszín jellemző adatainak fuzzy technikával való rangsorolásával, kombinálásával egy „Szélerózió Hajlam Indexet” (ILSWE - Index of Land Susceptibility to Wind Erosion) alkottak. Munkájuk jó alapot nyújthat a jövőbeli széleróziós modellezési tevékenységhez.

SCHMIDT et al. (2016) Nyugat Saxony terültére készített szélerózióérzékenységet vizsgáló modellt (SoLoWIND). A szélerősség, a szélirány, a talaj, a széleróziónak kitett terület és a védelmi zóna származtatott paramétereit fuzzy tagsági függvénnyel egyesítették. A modell szerint a szántóterületek közel egyharmadán nagy, vagy nagyon nagy a szélerózió veszélyeztetettség. A SoLoWIND jól láthatóvá tette az összefüggéseket a szélirány, szélerősség és a tájképi elemek között. 


\section{Összegzés}

A bemutatott tanulmányok alátámasztják MCBRATNEY és ODEH (1997), valamint JETTER és KOK (2014) összegzését, akik a fuzzy modellezés jelenlegi helyzetének részletes értékelése során kifejtették, hogy a fuzzy rendszerek és modellek a jövő fontos kutatási eszközei lehetnek. A „lágy” számítási módszerek a talaj- az, agrár- és a környezettudományok területén egyre nagyobb teret hódítanak meg. Nagy előnyt jelent a bizonytalan, nem vagy nehezen számszerüsíthető adatok használatának és a határvonalak nem éles, kategóriánként eltérő kijelölésének lehetősége. Megfelelő matematikai és interdiszciplináris kutatói hátteret feltételezve egyszerü, gyors és olcsó módszer, amely a hagyományos eljárásoknál pontosabb, és a laikusok által is értelmezhető eredményeket szolgáltat.

Kulcsszavak: fuzzy logika, talaj erózió, környezeti modellezés, vízerózió, szélerózió

\section{Irodalomjegyzék}

AGROTOPO Adatbázis, 1991: http://maps.rissac.hu/agrotopo_hu/

AKYUREK, Z. \& OKALP, K., 2006. A fuzzy-based tool for spatial reasoning: A Case study on soil erosion hazard prediction, In: 7th International Symposium on Spatial Accuracy Assessment in Natural Resources and Environmental Sciences. Edited by: M. Caetano and M. Painho.

Amini, M. Afyuni, M. FAthiAnPour, N. Khademi, H. FlÜHLER, H., 2005. Continuous soil pollution mapping using fuzzy logic and spatial interpolation. Geoderma 124. pp. 223-333.

Assimakopoulos, J.H. Kalivas, D. P. Kollias, V.J., 2003. A GIS-based fuzzy classification for mapping the agricultural soils for N-fertilizers use. The Science of the Total Environment. 309. pp. 19-33.

Astel, A., 2007. Chemometrics based on fuzzy logic principles in environmental studies. Talanta. 72. pp. 1-12.

BÁRDOSSY, A. \& DuCKSTEIN, L., 1995. Fuzzy rule-based modelling with applications to geophysical. Biological and Engineering Systems. CRC Press. New York. 113 pp.

BÁRDOSSY, A. Bogardi, I. Kelly, W. E., 1990 a. Kriging with imprecise (fuzzy) variogram, Part I. Mathematical geoscinces theory methods and applications. 22. 63-79.

BáRdossy, A. Bogardi, I. Kelly, W. E., 1990 b. Kriging with imprecise (fuzzy) variogram, Part II. Mathematical geoscinces theory methods and applications. 22. 81-94.

BezDeK, C. J. Ehrlich, R. Full, W., 1984. FCM: The fuzzy C-means clustering algorithm. Computers \& Geosciences. Volume 10. Issues 2-3. pp. 191-203.

BEZDEK, J. C., 1981. Pattern recognition wit fuzzy objective function algorithms. Plenum, New York. 
Bezdek, J.C. Keller, J. Krisnapuram, R. PAL, N.R., 1999. Fuzzy models and algorithms for pattern recognition and image processing. Kluwer Academy Publishers. Boston.

Bloch, I. \& MAITRE, H., 1995. Fuzzy mathematical morphologies: A comparative study. Pattern Recognition, Vol 28., No. 9., pp. 1341-1387.

Borelli, P. Panagos, P. Ballabio, C. Lugato, E. Weynants, M. Montanarella, L., 2014. Towards a Pan-European assessment of land susceptibility to wind erosion. Land Degradation \& Development. DOI: 10.1002/ldr.2318

Bragato, G., 2004. Fuzzy continous classification and spatial interpolation in conventional soil survey for soil mapping of the lower Piawe plain. Geoderma. 118. pp. 1-16.

Burrough, P. A., 1986. Principles of Geographical Information Systems for Land Resources Assessment. Clarendon Press, Oxford, 194 pp.

BurRough, P.A., 1989. Fuzzy mathematic methods for soil survey and land evaluation. Journal of Soil Scince. 40. 447-492.

Callott, Y. Marticorena, B. Bergametti, G., 2000. Geomorphologic approach for modeling the surface features of arid environments in a model of dust emissions: application to the Sahara Desert. Geodinamica Acta. 13. (5). pp. 245-270.

Camarinha, P.I.M. Trannin, I.C.B. Simoes, S.JC. Bernardes, G.P., 2011. Fuzzy logic and geostatistical techniques for spatialization of soil texture in region with rough terrains. Procedia Environmental Sciences. 7. pp. 347-352.

CANiAni, D. LiOI, D. S. MANCINI, I. M. MASI, S., 2011. Application of fuzzy logic and sensitivity analysis for soil contamination hazard classification. Waste Management, 31. pp. 583-594.

CARLSON, N. T. \& RIPLEY, A. D., 1997. Ont he relation between NDVI, fractional vegetation factor, and leaf area index. Remote Sensing of Environment. 62. (3). pp. 241-252.

Cohen, S. Svoray, T. Laronne, B. J. Alexandrov, Y., 2008. Fuzzy-based dynamic soil erosion model (FuDSEM): Modelling approach and preliminary evaluation. Journal of Hydrology. 356. pp. 185-198.

Cornelissen, A. M. G. Berg, J. Koops, W.J. Grossmann, M. Udo, H.M.J., 2001. Assessment of the contribution of sustainability indicators to sustainable development: a novel approach using fuzzy set theory. Agriculture, Ecosystems and Environment 86. pp. 173-185.

DANIELL, T. M., 1991. Neural networks - application in hydrology and water resources engineering. In: Proceedings of International Hydrology and Water Resources Symposium. Perth. Australia. pp. 791-802.

Davatgar, N. Neishabouri, M.R. SePaskah, A.R., 2012. Delineation of site specific nutrient management zones for a paddy cultivated area based on soil fertility using fuzzy clustering. Geoderma. 173-174. pp. 111-118.

DelcourT, H. R. \& DelcourT, P. A., 1988. Quaternary landscape ecology: Relevant scales in space and time. Landscape Ecol. 2. 23-44.

DEMIREL, T. \& TÜZÜN, S., 2011. Multi criteria evaluation of the methods for preventing soil erosion using fuzzy ANP: the case of Turkey. Proceedings of the World Congress on Engineering 2011. Vol. II. WCE 2011, July. 6-8. 2011. London. U.K.

DOBERMANN, A. \& OBERTHÜR, T., 1997. Fuzzy mapping of soil fertility - a case study on irrigated riceland int he Phillipines. Geoderma. 77. pp. 317-339. 
DomBI, J., 1988. Membership function as an evaluation, Fuzzy Sets and Systems 35. (1990) 1-21., North- Holland.

DoMBI, J., 1990. Membership function as an evaluation. Fuzzy sets systems. 35. pp. 121.

Eastman, J. R., Kyem, P. A. K., Toledano, J. JIN, W., 1993. GIS and decision making, Explorations in Geographical Information System Technology. Unitar. Genova. 4.

ENEA, M. \& SALEMI, G., 2001. Fuzzy approach to the environmental impact evaluation. Ecological Modelling. 135. pp. 131-147.

EUROPEAN ENVIRONMENT AGENCY. 2006: CORINE Land Cover Technical Guide: Addendum, EEA, Copenhagen.

FAO 1976. A framework for land evaluation. Soils Bulletin 32. FAO, Rome, 72 pp.

FEOLI, E. VUERICH, G. L. ZERIHUN, W., 2002. Evaluation of environmental degradation in northern Etiopia using GIS to integrate vegetation, geomorphological, erosion and socio-economic factors. Agriculture, Ecosystems and Environment. 91. pp. 313-325.

FERRARO, D. O., 2009. Fuzzy knowledge - based model for soil condition assessment in Argentinean cropping systems. Environmental Modelling \& Software. 24. pp. 359-370.

FilzMoser, P. \& VIERTL, R., 2004. Testing hypotheses with fuzzy data: the fuzzy p value. Metrika. 59. pp. 21-29.

FlanAGEN, D. C. \& NEARING, M. A., 1995. USDA Water - Erosion Prediction Project (WEPP), Hillslope Profile and Watershed Model Documentation Technical Documentation, NSERL Report 10. USDA - ARS National Soil Erosion Research Laboratory: West Lafayette.

Freissnet, C. ERLiCH, M. VAUCLIN, M., 1998. A fuzzy logic-based approach to assess imprecisions of soil water contamination modelling. Soil \& Tillage Research. 47. pp. 11-17.

GIORDANO, R. \&, LIERSCH, S., 2012. A fuzzy GIS-based system to integrate local and technical knowledge in soil salinity monitoring. Environmental Modelling \& Software. 36. pp. 49-63.

Gruijter, J.J. Walwoort, D. J.J. Bragato, G., 2011. Application of fuzzy logic to Boolean models for digital soil assessment., Geoderma, 166. pp. 15-33.

GustAFson, E.E. \& KESSEL, W., 1979. Fuzzy clustering with a fuzzy covariance matrix. Befoglaló mü: IEEE conference on Decision and Control. San Diego. pp. 761-766.

JÁSZBERÉNYI, I. LOCH, J. TAMÁS, J., 1999. Evaluation of sampling patterns using geostatistical methods to develop fertilisation practice. In: Stafford J.V. (szerk.) Precision Agriculture. 1999. Part I. Academic Press. Sheffield. pp. 91-100.

Halmos, P.R., 1914. Naive set theory, Litton Educational Publishing, Inc., USA, SPIN 11007098.

HeuvelinK, G. B. M., \& Burrough, P. A., 1993. Error propagation in logical cartographic modelling using Boolean methods and continous classification. Int. J. Geogr. Inf. Syst. 7. pp. 231-246.

HoDzA, P., 2010. Fuzzy logic and differences between interpretive soil maps. Geoderma. 156. pp. 189-199. 
HoOSBEEK, M. R. \& BRYANT, R. B., 1992. Towards the quantitative modeling of pedogenesis-A review. Geoderma 55. 183-210.

Hu, H. Chan, C. W. Huang, G. H., 2003. A fuzzy expert system for site characterization. Expert System Applied. 24. pp. 123 - 131.

HuAding, S. QINGXIAN, G. YongQING, Q. J. L. Yunfeng H., 2010. Wind erosion hazard assessment of the Mongolian Plateau using FCM and GIS techniques. Environmental Earth Science. 61. 689-697.

Illés, G. KovÁcs, G. BIDló, A. HeIL, B., 2006. Digital soil and landsite mapping in forest management planning. Agrokémia és Talajtan. 55. pp. 99-108.

JetTer, J. A. KOK, K., 2014. Fuzzy cognitive maps for futures studies - A methodoligac assessment of concepts and methods. Futures. 61. pp. 45-57.

KAMPHUIS, J. W., 1986. Calculation of littoral sand transport rate. Coastal Engineering. 10. (1). pp. 1-21.

KARABOGA, D. BAGIS, A. HAKTANIR, T., 2004. Fuzzy logic based operation of spillway gates of reservoirs during floods. Journal of Hydrologic Engineering. 9. (6). pp. 544-549.

Klik, A. SAVABI, M. R. Norton, L. D. Baumer, O., 1995. Application of WEPP hillslope model on Austria. Proc. Annual Conference of the American Water Resources Association (AWRA). Houston. Texas. pp. 313-322.

KLIR, J. G. \& JuAN, B., 1995. Fuzzy sets and fuzzy logic: Theory and Applications, Prentice Hall PTR Prentice-Hall Inc., Upper Saddle River, New Jersey. ISBN 013-101171-5.

KóCZY, T. L. \& TiKK, D., 2001. Fuzzy rendszerek. Typotex Eletronikus Kiadó Kft. Budapest

Kollias, V.J. \& KaLIVAS, D.P., 1998. The enhancement of a commercial geographical information system (ArcINFO) with fuzzy processing capabilities for the evaluation of land resources. Comput Electron Agric. 20. pp. 79 -95.

Kollias, V.J. \& Voliotis, A., 1991. Fuzzy reasoning int he development of geographical information systems FRSIS: a prototype of soil information system with fuzzy retrieval capabilities. International Journal of Geographical Information Sytems. 5. 209-223.

Kollias, V.J. Kalivas, D.P. YASsoglou, N.J., 1999. Mapping the soil resources of a recent alluvial plain in Greece using fuzzy sets in a GIS environment. Eur J Soil Sci. 50. pp. $261-273$.

Koncsos, L. JolÁNKAI, ZS. Koncsos, T. KoZMA, Zs., 2011. Környezeti rendszerek modellezése. BME Vízi Közmü és Környezetmérnök Tanszék. Elektronikus jegyzet

KovÁCS, Sz., 1993, Fuzzy logic control, M.Phil. theses, Technical University of Budapest, Faculty of Informatics and Electrical Engineering, Budapest, Branch of Computer Science.

KWEON, G., 2012. Delineation of site-specific prodctivity zones using soil properties and topographic attributes with a fuzzy logic system. Biosystems Engineering. 112. pp. 261-277.

LI, B. L. ENGLiSh, E. ZHU, A. X., 2005. Development of knowledge for predictive mapping using a fuzzy c - means classifications. In: LIU, M.L., CHEN, G.Q., YING, M.S., (szerk.) Fuzzy logic, soft computing and computational intelligence. Tsinghua University Press. Beijing. pp. 1205-1209. 
López, E. M. García, M. Schuhmacher, M. Domingo, J. L., 2008. A fuzzy expert system for soil characterization. Environmental International. 34. pp. 950-958.

LUH, G. C. \& LIN, C. Y., 2009. Structural topology optimization using ant colony optimization alghorithm. Applied Soft Computing. 9. (4). pp. 1343-1353.

MAKROPOUlOS, C. \& Butler, D., 2005. Spatial ordered weighted averaging: incorporating spatially variable attitude towards risk in spatial multi - criteria decision - making. Environmental Modelling Software. 21/1. pp. 69-84.

MALCZEWSKI, J., 2006, Ordered weighted averaging with fuzzy qantifiers: GIS based multicriteria evaluation for land-use suitability analysis, International Journal of Applied Earth Observation and Geoinformation. 8. pp. 270-277.

Mamdani, E. H. \& Assililan, S., 1975. An experiment in linguistic synthesis with a fuzzy logic controller. Int. J. of Man Machine Studies, 7(1):1-13.

Márquez, M. A. \& PÉrez-Guevara, E., 2010. Comparative analysis of erosion modeling techniques in a basin of Venezuela. Journal of Urban and Environmental Engineering, v.4, n.2, p. 81-104, ISSN 1982-3932.

MAYs, M.D. BogARDI, I. BARdossy, A., 1997. Fuzzy logic and risk - based soil interpretations. Geoderma. 77. pp. 299-315.

McBratney, A. B. \& OdEH, O. A. I., 1997. Application of fuzzy sets in soil science: fuzzy logic, fuzzy measurement and fuzzy decisions. Geoderma. 77. pp. 85-113.

McBratney, A. B., 1992. On variation, uncertainty and informatics in environmental soil management. Australian Journal Soil Research. 32. 623-633.

MCBRATNEY, A.B. \& MORAN, C.J., 1994. Soil pore structure modelling using fuzzy random pseudofractal sets. In: Ringrose-Voase, A.J., Humphreys, G.S., Soil Morphology: Studies in Management and Genesis. Proc. 9th. Working Meeting, Soil Micromorphpology, Townsville, Australia, pp. 495-506.

MCNeILL, M. F. \& THRO, E., 1994. Fuzzy Logic: A practical approach. Academic Press INC. London.

METTERnicht, G. \& GonZalez, S., 2005. FUERO: foundations of fuzzy exploratory model for soil erosion hazard prediction. Environmental Modelling \& Software. 20. pp. 715-728.

METTERNICHT, G., 2001. Assessing temporal and spatial changes of salinity using fuzzy logic, remote sensing and GIS. Foundations of an expert system. Ecological Modelling. 144. pp. 163-179.

METTERNICHT, G.I., 1998. Fuzzy classification of JERS - 1 SAR data: an evaluation of its performance for soil salinity mapping. Ecological Modelling. 111. pp. 61-74.

METTERNICHT, G.I., 2003. Categorical fuzziness: a comparison between crisp and fuzzy class boundary modelling for mapping salt-effected soils using Landsat-TM data and a classification based on anion ratios. Ecological Modelling. 168. pp. 371-389.

MeZŐsI, G. BlAnKA, V. BATA, T. KovÁCS, F. MEYER, B., 2013. Estimation of regional differencies in wind erosion sensitivity in Hungary. Natural Hazard Earth Syst. Sci. Discuss., 1, 4713-4750.

Minasny, B. \& MCBRATneY, A.B., 2002. FuzME version 3.0, Australian Centre for Precision Agriculture, The University of Sydney, Australia

Mitra, B. Scot, H. D. DiXon, C.J., MCKimmeY, J.M., 1998. Application of fuzzy logic to the prediction of soil erosion in a large watershed. Geoderma 86. pp. 183209. 
MonK, D. J., 2016. Stanford Encylopedia of Philosophy: The Mathematics of Boolean Algebra. ISSN: 1095-5054.

Moran, C.J. \& MCBRATneY, A.B., 1997. A two dimensional fuzzy random model of soil pore structure. Mathematical Geology, Vol. 29, No. 6, pp. 755-777.

Morgan, R. P. C. Quinton, J. N. Smith, R. E. Govers, G. Poesen, J.W. A. Auerswald, K. Chisci, G. TorRI, D. Styczen, M. E., 1998. The European Soil Model (EUROSEM): A dynamic approach for predicting sediment transport from fields and small catchments. Earth Surface Processes Landf. 23. (6). pp. 527-544.

Murmu, S. \& BISWAS, S., 2015. Application of fuzzy logic and neural network in crop classification: A review. Aquatic Procedia. 4. pp. 1203-1210.

NANDA, A. RATH, K. A. DINDA, B. RATH, R., 2011. Genetic fuzzy approach for prediction of coastal erosion, International Journal of Computer Information Systems, Vol. 2, No. 2.

NANDA, A. RATH, K. A. RouT, K. S., 2010. Real time wireless sensor network for coastal erosion using fuzzy interface system. International Journal of Computer Science \& Emerging Technologies. 1. (2). pp. 47-51.

NOAA, 2012: http://gis.ncdc.noaa.gov/map/viewer.

Odeh, I.O.A. MCBRATney, A.B. ChitTleborough, D.J., 1992. Soil pattern recognition with fuzzy c-means: application to classification and soil-landform interrelationships. Soil Sci. Soc. Am. 56, 505- 516.

ODEH, I.O.A., 1996. A fuzzy multi-criterial approach to field soil description: an example. Pedometrics Symposium, Organized by ACLEP and ISSS Working Group on Pedometrics, Melbourne, July 1-4. pp. 201-202.

ÖZDEMIR, N., 2002. Soil and Water Protection (Toprak ve Su Koruma), Samsun.

PARCHAMI, A. IVANI, R. MASHINCHI, M., 2010. An application of testing fuzzy hypotheses: Soil study on the bioavailability of cadmium. Scientica Iranica C. 18. (3), 470-478.

Parchami, A. TAheri, S. M. Mashinchi, M., 2010. Fuzzy p - value in testing fuzzy hypotheses with crisp data. Statistical Papers. 51 (1). pp. 209-226.

PECHE, R. \& RodRÍGUEZ, E., 2009. Environmental impact assessment procedure: A new approach based on fuzzy logic. Environmental Impact Assessment Review. 29. pp. 275-283.

PECHE, R. \& RoDRíGueZ, E., 2012. Development of environmental quality indexes based on fuzzy logic. A case study. Ecological Indicators. 23. pp. 555-565.

PIROS, A. \& Veres, G., 2013. Fuzzy based method for project planning of the infrastructure design for the diagnostic in ITER. Fusion Engineering And Design 88. pp. 1183-1186.

PlyUSNIN, I., 1964. Reclamative Soil Science. Foreign Languages Publishing House, Moscow.

Pongracz, R. BogARdi, I. DuCKSTEIN, L., 2011. Application of fuzzy rule-based modelling technique to regional drought. Journal of Hydrology. 224. pp. 100-114.

Promentilla, M. A. B. Furuichi, T. Ishit, K. TANikAwA, N., 2008. A fuzzy analytic network process for multi -criteria evaluation of contaminated site remedial countermeasures. Journal of Environmental Management. 88. pp. 479-495.

RAINES, G. L. SAWATZKY, D. L. BONHAM-CARTER, G. F., 2010. Incorporating Expert Knowledge: New fuzzy logic tools in ArcGIS 10., ArcGIS 10 Softver Guide. 
RAJKAI, K., 2001. Modellezés és modellhasználat a talajtani kutatásban. Agrokémia és Talajtan Tom. 50. No. 3-4. 469-508. pp.

ROBINSON, V. B. \& STRAHLER, A. H., 1984. Issues in designing geographic information systems under conditions of inexactness. Machine Processing of Remotely Sense Data, pp. 179-188.

Saboya, F. Alves, G. M. Pinto, W. D., 2006. Assesment of failure susceptibility of soil slopes using fuzzy logic. Engineering Geology. 86. pp. 211-224.

Sami, M. Shiekhdavoodi, J. M. Pazhohanniya, M. Pazhohanniya, F., 2014. Environmental comprehensive assessment of agricultural systems at farm level using fuzzy logic: A case study in cane farm sin Iran. Environmental Modelling \& Software. 58. pp. 95-108.

SÁrbU, C. ZEHL, K. EINAX, W. J., 2007. Fuzzy divisive hierarchical clustering of soil data using Gustafson-Kessel algorithm. Chemometrics and Intelligent Laboratory Systems. 86. pp. 121-129.

SATtLer, C. StaCHOw, U. Berger, G., 2012. Expert knowledge-based assessment of farming practices for different biotic indicators using fuzzy logic. Journal of Environmental Management. 95. pp. 132-143.

Schmidt, S. Meusburger, K. Figuerideo, T. Alewell, C., 2016. Modelling hot spots of soil loss by wind erosion (SoLoWIND) in Western Saxony, Germany. Land Degradation Development. DOI.: 10.1002/ldr.2652.

SElye, J., 1967. Álomtól a felfedezésig. Egy tudós vallomásai. Akadémiai Kiadó, Budapest, Eredeti: From Dream to Discovery. Confession of a Scientist. (Ford. Józsa Péter). New York-Toronto-London, McGraw-Hill.

SILVERT, W., 2000. Fuzzy indices of environmental conditions. Ecological Modelling. 130. pp. 111-119.

Simons, D. B. LI, R. M. Fullerton, L., 1981. Theoretically derived sediment transport equations for Prima County, Arizona. Prepared for Pima County DOT and Flood Control District. Tucson. Arizona. Colorado.

STEINHARDT, U., 1998. Applying the fuzzy set theory for medium and small scale landscape assessment. Landscape and Urban Planning 41. pp. 203-208.

SUI, D. Z., 1992. A fuzzy GIS modelling approach for urban land evaluation. Computer Environment and Urban Systems. 16. 101-115.

SzABÓ, J. PÁSZTOR, L. BAKACSI, Zs., 2005. Egy országos, átnézetes, térbeli talajinformációs rendszer kiépítésének igénye, lehetőségei és lépései. Agrokémia és Talajtan. 54. pp. 41-58.

TAMÁs, J. CSILlaG, J. MuRÁNYI A., 1997. Risk mapping of potentially toxic element's pollution by modelling combined effects of $\mathrm{pH}$, clay mineral and organic matter. In: Filep György, Soil, Water and Environmental Relationship: Soil Pollution. 1998, Rexpo Ltd. Debrecen, ISBN: 9630364069.

TAMÁS, J. MÉZES, L. BÍRÓ, GY. NYÍRCSÁK, M. BORBÉLY, J., 2012. Fuzzy system to optimize the anaerobic digestion in biogas reactors. In: Proceedings of 8th. International Conference ORBIT 2012. France, Rennes. pp. 35-39.

TAYFur, G. OZDEMIR, S. Singh, P. V., 2003. Fuzzy logic algorithm for runoff-induced sediment transport from bare soil surfaces. Advances in Water Resources. 26. pp. 1249-1256.

TAYFUR, G., 2002. Artificial neural networks for sheet sediment transport. Hydrological Sciences Journal IAHS. 47/6. 
Tóth, Zs. E. \& JóNÁS, T., 2014. Fuzzy elmélet a menedzsmentben. Elektronikus Oktatási Segédanyag. Budapest.

Tran, L.T. Ridgley, M.A. DuCKStein, L. Sutherland, R., 2002. Application of fuzzy logic-based modelling to improve the performance of the revised universal soil loss equation. Catena 47. pp. 203-226.

Ure, A.M. Quevauviller, Ph. MunTAU, H. GRIEPINK, B., 1993. a. Specation of heavy metal in soils and extraction techniques undertaken under the auspices of BCR of the Comission of the European Communities. Internationak Journal of Environmental and Analitical Chemistry. 51. pp. 135-151.

Ure, A.M., Quevauviller, Ph., Muntau, H., GriePink, B., 1993. b. Specation of heavy metal in soils and sediments - an account of the improvements and harmonisations of extraction techniques undertaken under the auspecies of the BCR of the Comission of the European Communities. Internationak Journal of Environmental and Analitical Chemistry. 51. pp. 135-151.

USGS LP DAAC Data Pool Database, 2012: http://e4eil01.cr.usgs.gov:22000/WebAccess/drill?attrib=esdt\&esdt=MOD13Q1.5 \&group=MOLT.

WANG, S. Z. ZhAO, Z. H. XIA, B. QIU, H. MoREL, J. L. QIU, R. L., 2014. A fuzzy-based methodology for an aggregative environmental risk assessment of restored soil. Pedosphere. 24(2): 220-231.

WATERSTONE, M., 1994. Institutional analysis and water resources management. In: Druckstein, L., Parent, E., Natural Resources Management. Kluver, Dordecht.

ZADEH, L. A., 1973. Outline of a new approach to the analysis of complex systems and decision processes. IEEE Trans. on SMC, 1(1):28-44.

ZADEH, L.A., 1965. Fuzzy sets, Information and Control 8, pp.338-353.

ZHAO, S. X., 1986. Discussion on fuzzy clustering. In: Proceedings of the Eighth International Conference on Pattern Recognition. IEEE Press. New York. pp. 612614.

Zhu, A. X. Wang, R. QiaO, J. QIn, C.Z. Chen, Y. LiU, J. Du, F., 2014. An expert knowledge-based approach to landslide susceptibility mapping using GIS and fuzzy logic. Geomorphology. 214. pp. 128-138.

ZhU, A. X. YAnG, L. LI, B. QIN, C. PeI, T. LIU, B., 2010. Construction of membership functions for predictive soil mapping under fuzzy logic. Geoderma 155. pp. 164174.

Zhu, A-X. BAnd, L. E. Dutton., B. Nimlos, T. J., 1996. Automated soil inference under fuzzy logic. Ecological Modelling. 90. pp. 123-145. 


\title{
Fuzzy logic in agricultural and environmental research
}

\author{
K. TATÁRVÁRI ${ }^{1}$ and A. PIROS ${ }^{2}$ \\ ${ }^{1}$ Department of Water and Environmental Sciences, Faculty of Agriculture and \\ Food Science, Széchenyi István University, Mosonmagyaróvár \\ ${ }^{2}$ Department of Machine and Product Design, Budapest University of \\ Technology and Economics, Budapest
}

\begin{abstract}
Summary
The papers presented support the summaries of MCBRATNEY and ODEH (1997) and JETTER and KOK (2014), who stated during the detailed evaluation of the present state of fuzzy modelling, that fuzzy systems and models may be the important research methods of the future. "Soft" computing methods are gaining ever more ground in the field of soil, agricultural and environmental sciences. The possibility of setting boundaries that are not defined as categories with precisely set, distinctive definitions, and of working with data that are not easily quantifiable and insecure presents a great advantage. Provided a satisfactory mathematical and interdisciplinary research background is available, this is a comparatively simple, fast and cost-effective method, which is more exact than conventional ones, and which supplies results that can also be understood by laymen.
\end{abstract}

Keywords: fuzzy logic, soil erosion, environmental modelling, water erosion, wind erosion 